International Journal of Applied Linguistics \& English Literature

ISSN 2200-3592 (Print), ISSN 2200-3452 (Online)

Vol. 1 No. 5; September 2012 [Special Issue on General Linguistics]

\title{
Null Arguments in the Yoruba Child's Early Speech
}

\author{
Bolanle Elizabeth Arokoyo, $\mathrm{PhD}$ \\ Department of Linguistics and Nigerian Languages, University of Ilorin \\ P. M.B. 1515, Ilorin, Kwara State, Nigeria \\ Tel: +2348033780568Ｅ-mail: bolakoyo@yahoo.com
}

Received: 07-05- 2012

Accepted: 27-07- 2012

Published: 03-09- 2012

doi:10.7575/ijalel.v.1n.5p.116

URL: http://dx.doi.org/10.7575/ijalel.v.1n.5p.116

\begin{abstract}
This paper studied null arguments in the early speech of the Yoruba child. We examined whether null subjects are more prominent than null objects and whether the usage of null subjects decreases with language development in the early utterance of the Yoruba child. We also examined the relationship between argument ellipses and finiteness. Minimalist Programme was adopted as the theoretical framework because of its provision for minimality in the processes of language acquisition. The database was made up of longitudinal naturalistic speech output of three Yoruba-speaking children between 15and 36 months of age. We discovered the preponderance of null argument-NPs at the initial stage; subjects-NPs were easily omitted while object-NPs were hardly omitted; the three Yoruba-speaking children began to make use of overt argument-NPs from fifteen months and gradually, null argument-NPs gave way. We found no direct relationship between the acquisition of finiteness and the end of null arguments.
\end{abstract}

Keywords: arguments, null, object, subject, finiteness, ellipses

\section{Introduction}

This paper presents findings on acquisition of null arguments in the early speech of the Yoruba child. Finite clauses in Yoruba with the exception of imperative clauses require overt subjects. There are however a number of languages that do not require overt subjects in finite clauses; those languages are called pro-drop languages. A very good example of such languages is Italian. It has however been observed that a well-known characteristic of early grammars is null arguments; that is the omission of subjects and objects. Several studies have discovered that children acquiring non-pro-drop languages allow non-overt subjects in finite clauses and that they also elide objects (Hyams 1986, Sano and Hyams 1994, Radford, 2000, Lorusso, Caprin and Guasti 2004, Cabré Sans and Gavvaro, 2006, Grüter, 2006, 2007). Aronoff (2003) says that null subjects appear to be a universal phenomenon in language acquisition.

Hyams (1986) investigates the acquisition of null and overt subjects in English and Italian. The work is an innatist approach following the principles and parameters account of language acquisition. She argues that subjects of the matrix clause in English must be overtly expressed, while in Italian, it may be null. Hyams (1986) observes that children acquiring both English and Italian do omit the matrix subjects of their sentences. She also argues that the proposed pro-drop parameter could account for the ellipsis of pronominal subjects in child language. She proposes that the initial setting of the Null Subject Parameter allows matrix null subjects. She proposes that early subject drop results from a mis-setting of the Null Subject Parameter.

Sano and Hyams (1994) assume a relationship between pro-drop in child language and the use of root infinitive structures and the development of inflection by children. They propose that early null subjects should be identified as PRO (null NP that appears in caseless positions). They believe that the presence of root infinitives in early child language leads to pro-drop. The PRO analysis, according to Rohrbacher and Vainikka (1994), maintains that subjectless non-finite matrix clauses are full-fledged Complemetizer Phrases (CPs) which lack AgrS-features. As a consequence, the verb does not have to move to Subject-Agreement Phrase (AgrSP) at Logical Form (LF) and Spec of Subject-Agreement Phrase (AgrSP-Spec) remains ungoverned, thus constituting a possible site for PRO. Lee (2000:101) states that 'if children's main clauses can be non-tensed, the subject position of theses clauses will be ungoverned, and PRO will be licensed, hence the possibility of null subjects in root clauses'. 
International Journal of Applied Linguistics \& English Literature

ISSN 2200-3592 (Print), ISSN 2200-3452 (Online)

Vol. 1 No. 5; September 2012 [Special Issue on General Linguistics]

Null arguments according to Radford (2000:8) "are null nouns which are given a null spell-out by virtue of representing given information". He examines the transcripts of Allison at 22 months. He states that Allison produces a large number of sentences with missing arguments. He finds that $76 \%$ of the verbs she produced had a null subject while $51 \%$ of the transitive verbs she produced had a null object. He opines that those sentences involve 'syntactically projected null arguments' which are directly theta-marked by the verb. He gives the structure for baby eat as follows:

\section{1. $\quad[\mathrm{vP}[\mathrm{N}$ Baby] [[V ø] [VP[[V eat] [N Ø ]]]]}

He assumes that null arguments are null nouns which are given null spell-out by virtue of representing given information. He states that the overt nouns and the null nouns that Allison uses is $\phi$-incomplete and lacks person and case properties. He concludes that the merger of a verb with a null $\phi$-incomplete noun involves $\theta$-marking relation between $\mathrm{V}$ and $\mathrm{N}$ which by implication means there is no case or agreement.

Cabré Sans and Gavarró (2006) also study the acquisition of subjects in Catalan, a null subject language. They used the longitudinal data of three Catalan-speaking children, Pep, Gisela and Júlia, with age ranging from 18 to 32 months and the speech of the adults interacting with them. They observe that there is no period in which subjects are banned from the speech of children. They state that the early emergence of subjects witnesses not only the availability of mechanisms of the computational system, but also sensitivity to the pragmatic interface which dictates use of overt subjects.

Uziel-Karl and Berman (2000) examine the learning of word-order constraints under conditions of object ellipsis. The paper sees acquisition as a stepwise process. The data for the research is a longitudinal corpus collected from four children between the ages of 17 and 28 months and also supplemented by other data. The authors propose different explanations of argument ellipsis at different ages. The authors believe that both grammatical and discourse factors would account for the null arguments in the Hebrew child language. They discuss three factors that influence argument ellipsis. These factors are: permissibility, recoverability and syntactic function. They conclude that pragmatic factors will account for the ellipsis of subject for the younger children while subject ellipsis of the older children is conditioned by morpho-syntactic rules of the language.

Allen (2000) examines the factors that contribute to the inclusion or omission of arguments in the longitudinal speech of four Inuktitut children aged between 24 to 42 months. Allen shows that young children are sensitive to the dynamics of information flow (Bavin 2000). She believes that null arguments in child language cannot be accounted for only by grammar-based theories. She argues for an integrated approach of theories of grammar and of discourse pragmatics. In agreement with Uziel-Karl and Berman (2000) and Allen (2000), we also believe that an integrated approach to the study of language acquisition could help to bring out other factors that are involved in language acquisition.

Sano and Hyams (1994) propose that the acquisition of finiteness will mean the end of the null subject period for the English-speaking child. Lee (2000) studies the development of Chinese. He states that finiteness has no effect on the occurrence of empty elements. According to Huang (1982) as quoted from Lee (2000:110), if a sentence takes aspect marking or contains a modal, then it should be considered finite. Rohrbacher and Vainikka (1994:13) who examine German verb syntax under age 2, state that similar results are reported for older children acquiring German, Flemish, Dutch, and English in Poeppel and Wexler (1993), Krämer (1993), Haegeman (1994) and Sano and Hyams (1994). As stated earlier, Yoruba does not attest tense morphology, there is no built-in distinction between past and present (Rowland, 1969). We use the presence of modal in a sentence to indicate that a child has acquired finiteness. As Lee (2000) assumes, we also assume that finiteness has no effect on null arguments.

Stromqvist and Ragnarsdottir (2000) investigate the use of subject arguments and distribution of spatial arguments by a child acquiring Swedish in the age range 22-24 and 24-26 months respectively. They also study a child acquiring Icelandic at 24-26 months. Stromqvist and Ragnarsdottir (2000) believe that both input and pragmatic factors influence the distribution of arguments in the early stages of acquisition. Unlike Uziel-Karl and Berman (2000), they do not believe in a processing explanation for subject ellipsis. They argue that there are constraints that govern the ellipsis of these arguments. They also state that these constraints are mastered gradually. They conclude that input factors and pragmatic play important role in explaining the structure of the earliest phases of the acquisition of verb arguments.

With empirical evidence from the Yoruba child, we make the following predictions:

a. The Yoruba child acquires null arguments during early language development. 
International Journal of Applied Linguistics \& English Literature

ISSN 2200-3592 (Print), ISSN 2200-3452 (Online)

Vol. 1 No. 5; September 2012 [Special Issue on General Linguistics]

b. Null subjects are more prominent than null objects in the early utterance of the Yoruba child.

c. The rate of usage of null subjects decreases with language development and a co-relational increase in overt subjects in the child Yoruba.

d. Argument ellipses are not dependent on finiteness.

\section{Methodology}

Damilare is the first child of educated middle class parents. The parents live and work in Ilorin, the Capital City of Kwara State, Nigeria. The data presented for him covers a period of 15 to 36 months. The data were collected by the mother (the researcher) on a daily basis. Damilare's data consist of questions, responses and utterances between him and the parents and other members of the family. It also included his utterances while playing alone. We could safely say that the exercise made it possible to know at each point he has acquired anything linguistically significant. The best form of longitudinal data collection should be between a child and any of the parents or someone who lives with the family. This enables close interaction with the child which aids easy data collection. This also removes most possible constraints that may arise.

Temiloluwa and Tola are a set of female twins of educated middle class parents. The parents live and work in Ilorin. They have two older siblings, a brother and a sister. The data presented for them in this study cover from 15 months to 36 months. The data were collected by their father daily at home and in other possible situations. The data consist of utterances, responses, questions between the two of them, with their parents and siblings and other members of the family.

The data were transcribed immediately after recording into a notebook. Thereafter, the data is typed and stored in the computer for further analysis. All the utterances of the three children were coded for their lexical composition. We took into consideration the bottom-up fashion of building up structure by the children. We carry out a quantitative and qualitative analysis of data. The quantitative analysis uses simple mathematical calculations with the aid of tables and charts. The tables show the percentage of observed phenomena. The bar charts, drawn from the tables are used to show comparison between different items at a particular point in time. The qualitative analysis relies on explanations and tree diagrams.

\section{Theoretical Framework}

The syntactic analysis is carried out using the Minimalist Programme (MP). The idea behind minimalism is that grammars should be as simple as possible. Chomsky is of the opinion that linguistic theory should provide grammars which make use of the minimal theoretical apparatus required to provide a descriptively adequate characterization of linguistic phenomenon. This is a clear departure from the earlier phases of generative grammar with its phrase structure rules and transformational rules. The essential spirit of minimalism is to reduce the theoretical apparatus which we use to describe syntactic structure to a minimum (Radford, 2004:73). The Minimalist Programme, according to Carnie (2002:315), 'is motivated not only by the search for explanatory adequacy, but also for a certain level of formal simplicity and elegance'.

The desire to minimize the acquisition burden placed on the child and thereby maximizes the learnability of natural language grammars led to the beginning of the program (Radford, 1997:7). Language acquisition within the Minimalist Programme is seen as a matter of learning vocabulary, we all speak the same language differing only in vocabularies (Cook, 1996). The program focuses on the process of building up syntactic structures. According to Longa and Lorenzo (2008:541) MP 'redefined the meta-theoretical role of the theory of acquisition within generative grammar'. The use of two-word utterance by children is believed to be the beginning of grammar.

The programme focuses on the process of building up syntactic structures. A phrase is formed by merging two words. Chomsky (1995:396) says it is "an operation that forms larger units out of those already constructed". Chomsky (1999:2) further describes merge as "the indispensable operation of a recursive system"; he further states that this operation "comes free". It is always a binary relation; it combines two partial trees to form something new. Merge operation is formulated as:

$$
\operatorname{Merge}(a, \beta):=[\lambda \alpha \beta] \quad(\text { where } \lambda \text { is the label of the resulting tree) }
$$

(Lechner, 2006:4)

Merge does not impose any restrictions on the output order of the combining elements. According to Lechner (2006), it doesn't matter whether read is merged with the book resulting in[read read the book] or [read the book read]. This fact makes it easy to account for early development of language by children. As there are points when there seems to be no restriction in the way they merge elements in their utterances. Following Chomsky

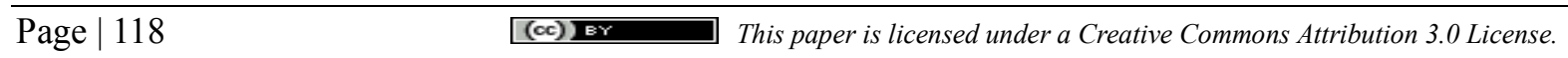




\section{International Journal of Applied Linguistics \& English Literature}

ISSN 2200-3592 (Print), ISSN 2200-3452 (Online)

Vol. 1 No. 5; September 2012 [Special Issue on General Linguistics]

(2004), merge can apply in two types of configurations leading to two types of operations. These are the external or root merge and the internal merge. The external merge is the classic merge operations that lead to structure building and extension while the internal merge refers to Move. Children's language at the early stage involve external merge.

\section{The Yoruba child acquires null arguments during early language development.}

Across languages, children miss out arguments at the initial stage of acquiring their language. The argument that is missed could be the subject, direct object or indirect object. It is assumed that missing subjects are more readily licensed than missing objects (Hyams 1983, 1986; Wang, Lillo-Martin, Best \& Levitt 1992, Hyams \& Wexler 1993, Uziel-Karl 2001). In Yoruba, argument positions must be filled. This means that a transitive verb for example, must have two arguments, the subject which is the external argument and the direct object; the internal argument. These are canonical argument positions. These are however missing in the early speech of the Yoruba child. Table 1 provides information about null arguments in the longitudinal speech of Damilare, Temiloluwa and Tola.

Table 1. Null NPs in the Yoruba Child: Longitudinal Data from Three Children

\begin{tabular}{|llcc|}
\hline Child & Age & \% of Null Subjects & $\%$ of Null Objects \\
Damilare & 17 & $93 \%$ & $38.5 \%$ \\
& 18 & $94.4 \%$ & $0 \%$ \\
& 19 & $94.3 \%$ & $1.9 \%$ \\
& 20 & $87.1 \%$ & $0 \%$ \\
Temiloluwa & 21 & $23.9 \%$ & $0 \%$ \\
& 22 & $34.5 \%$ & $0 \%$ \\
& 23 & $31.7 \%$ & $0 \%$ \\
& 17 & $36.1 \%$ & $11.2 \%$ \\
Tola & 18 & $13.6 \%$ & $0 \%$ \\
& 20 & $12.5 \%$ & $0 \%$ \\
& 21 & $7.14 \%$ & $0 \%$ \\
& 22 & $0 \%$ & $0 \%$ \\
& 23 & $0 \%$ & $0 \%$ \\
& 17 & $0 \%$ & $0 \%$ \\
& 18 & $66.7 \%$ & $33.5 \%$ \\
& 19 & $25 \%$ & $33.3 \%$ \\
& 22 & $22 \%$ & $0 \%$ \\
& 22 & $14.8 \%$ & $0 \%$ \\
\hline
\end{tabular}

The findings in Table 1 show the preponderance of null subjects at the early stage of the children's language acquisition, ranging from $93 \%$ to $36 \%$. The incidence of null objects as indicated in the data and represented in the table does not show any regular pattern. The children show a minimal percentage of object drop as seen in figure 1 below: 
International Journal of Applied Linguistics \& English Literature

ISSN 2200-3592 (Print), ISSN 2200-3452 (Online)

Vol. 1 No. 5; September 2012 [Special Issue on General Linguistics]

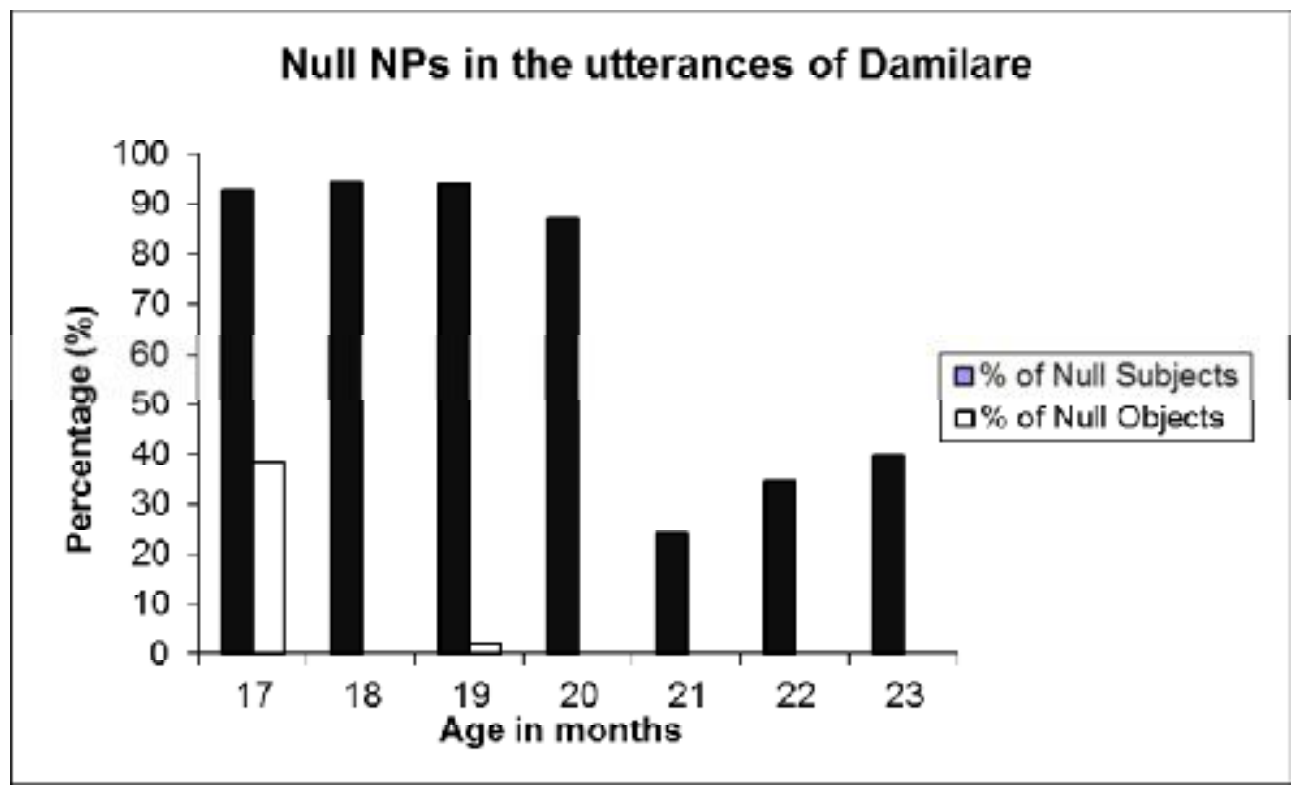

Figure 1. Null NPs in the Utterances of Damilare

In order to have a clear understanding of the phenomenon, we present the following data from Damilare, Temiloluwa and Tola.

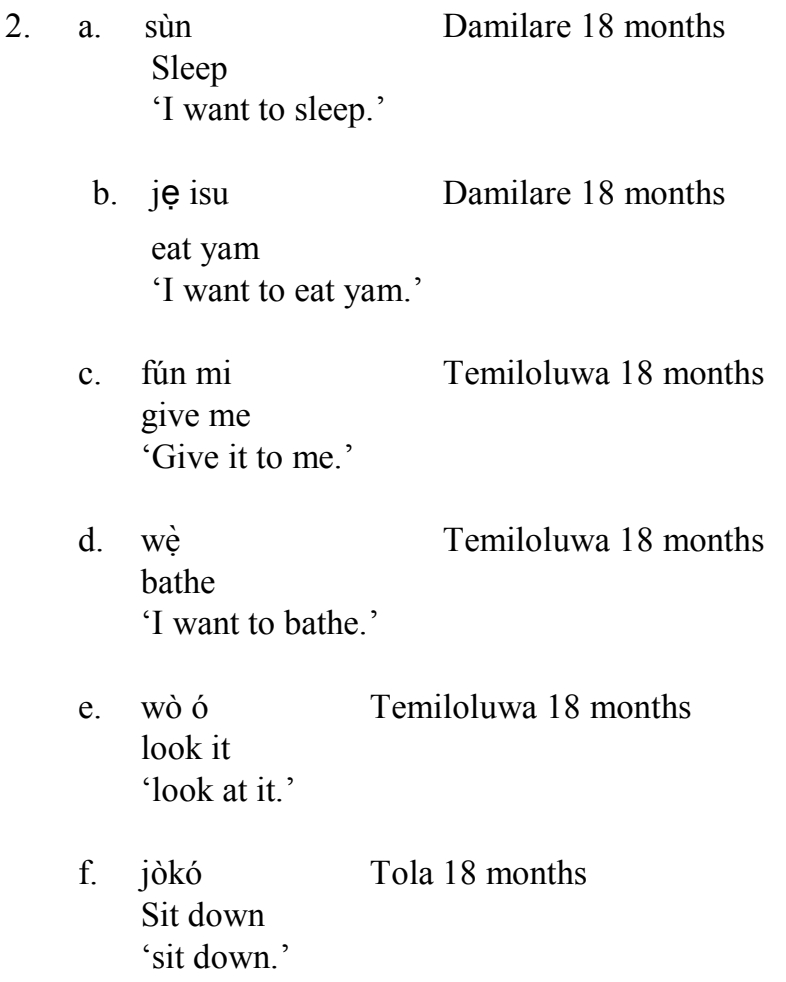

From the examples above, we see that the children have a high percentage of subject elision. Radford (2000) assumes that children freely allow arguments and predicates to be null if they are given information. Given information is information that is assumed to be shared by the speaker and the listener and does not need to be repeated. He claims that in a perfect language, lexical items could have a null Phonetic Form spell-out (PF-Spell-out) if their content can be pragmatically determined. Ellipsis of phrases, the gapping of heads and the zeroing of arguments are instances of null PF-spell-out in adult language. The children's use of null arguments characterizes a case of null PF spell-out. They take the missing subjects as given information. When we consider 
International Journal of Applied Linguistics \& English Literature

ISSN 2200-3592 (Print), ISSN 2200-3452 (Online)

Vol. 1 No. 5; September 2012 [Special Issue on General Linguistics]

the following example from Damilare
3. sí i mọ́to
Damilare 18 months
open it car
'open the car.'

It seems that he takes the subject $d a d d y$ as given. The discourse involved him and his father. He gave the car key to him and asked him to open the door of the car. There are also instances where the predicate is taken as given. Those are instances when there are Noun-Noun collocations. The following examples are taking from Damilare' transcripts:
4. a. mọ́mì bọọl
18 months
mummy ball
'Mummy give me the ball.'
b. màmá asọ 20 months
mummy clothe
'Mummy wear my clothe for me.'
c. bàbá mọ́tò
Daddy car
'Daddy has gone to the car.'
21 months

d. ifeoma yoyoyo fridge

Ifeoma youghourt frideg

'Ifeoma put the yoghurt in the fridge.'

When Damilare at 18 months says mọmi bool 'mummy ball', he treats the verbs fún 'give' as given and not needing any spell-out, hence the null appearance. According to Radford (2000), what Allison, his subject has failed to learn is that English imposes syntactic constraints on zeroing. This is also true of Yoruba. There are syntactic constraints that make it impossible to have a sentence without a subject or a sentence without a predicate.

We assume that because the subject is higher up in the hierarchy which makes it more prominent than others, the child assumes it is a given information shared by him and the listener and so it is elided (left out) but it is there underlyingly. This makes it covert argument rather than null. It is therefore not absent, only not realized phonetically; it is a null PF-spell out.

\section{Null Subjects are more Prominent than Null Objects in the Early Utterance of the Yoruba Child.}

The subject and object positions are canonical argument positions that must be filled in Yoruba language. As observed above, children miss out arguments at the initial state in the course of acquiring the argument structure of their language. We however discover that there are more null subjects than null objects in the speech of the Yoruba child. Table 2 answers the question of whether null subjects are more prominent than null objects in the early speech of the Yoruba child.

Table 2. Null Subjects are more Prominent than Null Objects in the Yoruba Child: Longitudinal Data from Three Children

\begin{tabular}{|llcc|}
\hline Child & Age & of Null Subjects & $\%$ of Null Objects \\
Damilare & 17 & $93 \%$ & $38.5 \%$ \\
& 18 & $94.4 \%$ & $0 \%$ \\
& 19 & $94.3 \%$ & $1.9 \%$ \\
& 20 & $87.1 \%$ & $0 \%$ \\
Temiloluwa & 21 & $23.9 \%$ & $0 \%$ \\
& 22 & $34.5 \%$ & $0 \%$ \\
& 17 & $31.7 \%$ & $0 \%$ \\
& 18 & $36.1 \%$ & $11.2 \%$ \\
\hline
\end{tabular}


International Journal of Applied Linguistics \& English Literature

ISSN 2200-3592 (Print), ISSN 2200-3452 (Online)

Vol. 1 No. 5; September 2012 [Special Issue on General Linguistics]

\begin{tabular}{|clll|}
\hline \multirow{6}{*}{ Tola } & 20 & $7.14 \%$ & $0 \%$ \\
& 21 & $0 \%$ & $0 \%$ \\
& 22 & $0 \%$ & $0 \%$ \\
& 23 & $0 \%$ & $0 \%$ \\
& 17 & $66.7 \%$ & $33.5 \%$ \\
& 18 & $25 \%$ & $33.3 \%$ \\
& 19 & $22 \%$ & $0 \%$ \\
& 20 & $20 \%$ & $0 \%$ \\
& 21 & $14.8 \%$ & $0 \%$ \\
& 22 & $0 \%$ & $0 \%$ \\
\hline
\end{tabular}

Taking a look at the speech of the three children, we discover that Damilare at 17 months records $93 \%$ of null subjects while null objects was $38.5 \%$. Temiloluwa at 17 months records $36.1 \%$ of null subjects and $11.2 \%$ of null objects while Tola's null subjects at 17 months are $66.7 \%$, her null objects stood at $33.5 \%$. From the foregoing, we can say that null subjects are more prominent than null objects in the early speech of Yoruba children. Figure 2 below further illustrates this fact.

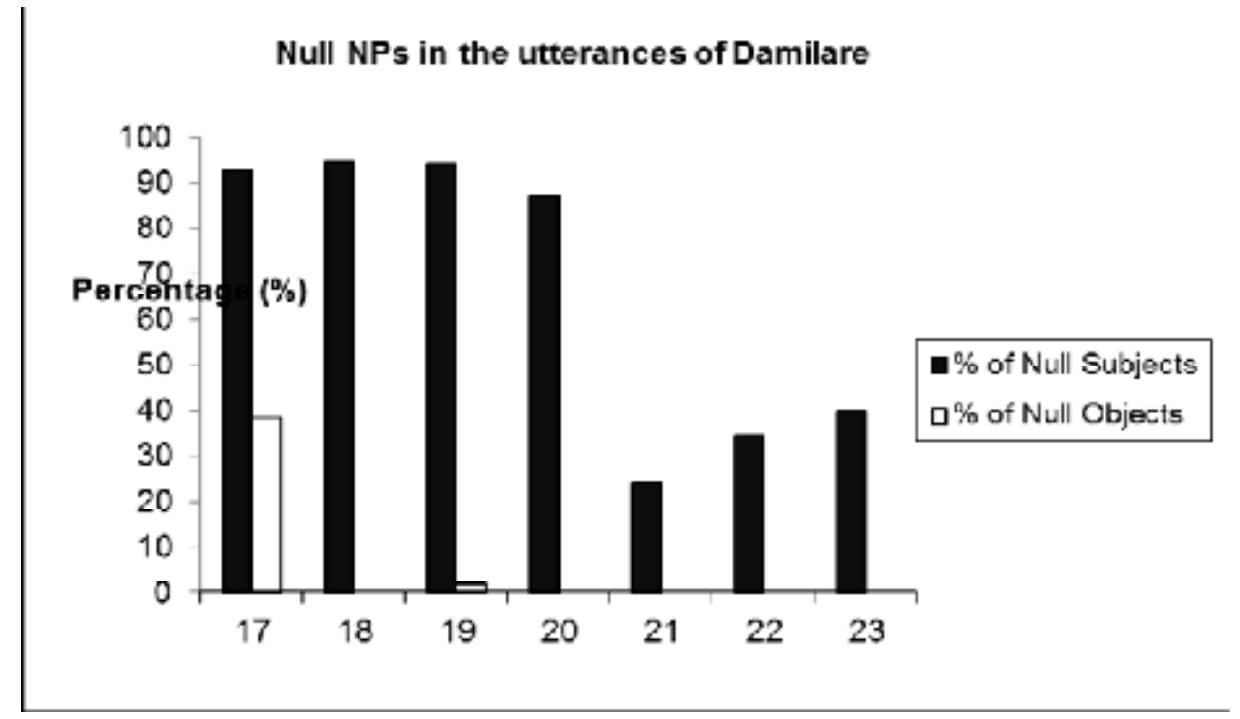

Figure 2. Null NPs in the Utterances of Damilare

We can see from the chart above that null subjects are more prominent in the speech of Damilare than null objects and also that null subjects decrease with age just as null objects.

6. The rate of usage of null subjects decreases with language development and a co-relational increase in overt subjects in the child Yoruba.

At the initial stage, there is a high level of null subjects. With time, the amount of overt subjects will increase with a co relational decrease in null subjects. Table 3 shows that null subjects gradually give way to overt subjects while a graphic representation of this information is given in Figure 3 below.

Table 3. Distribution of Null and Overt Subject NPs in the Early Sentences of the Yoruba Child: Longitudinal Data from Three Children

\begin{tabular}{|lccc|}
\hline Child & Age & $\%$ of Null Subjects & $\%$ of Overt Subjects \\
Damilare & 17 & $93 \%$ & $7 \%$ \\
& & & \\
& 18 & $94.4 \%$ & $5.6 \%$ \\
\hline
\end{tabular}


International Journal of Applied Linguistics \& English Literature

ISSN 2200-3592 (Print), ISSN 2200-3452 (Online)

Vol. 1 No. 5; September 2012 [Special Issue on General Linguistics]

\begin{tabular}{|llll|}
\hline & 19 & $94.3 \%$ & $5.7 \%$ \\
20 & $87.1 \%$ & $12.9 \%$ \\
& 21 & $23.9 \%$ & $76.1 \%$ \\
& 22 & $34.5 \%$ & $65.5 \%$ \\
Temiloluwa & 23 & $31.7 \%$ & $68.3 \%$ \\
& 17 & $36.1 \%$ & $63.9 \%$ \\
& 18 & $13.6 \%$ & $86.4 \%$ \\
& 19 & $12.5 \%$ & $87.5 \%$ \\
& 20 & $7.14 \%$ & $92.9 \%$ \\
& 21 & $0 \%$ & $100 \%$ \\
22 & $0 \%$ & $100 \%$ \\
& 23 & $0 \%$ & $100 \%$ \\
& 17 & $66.7 \%$ & $33.3 \%$ \\
18 & $25 \%$ & $75 \%$ \\
19 & $22 \%$ & $78 \%$ \\
20 & $20 \%$ & $80 \%$ \\
21 & $14.8 \%$ & $85.2 \%$ \\
22 & $0 \%$ & $100 \%$ \\
& 23 & $0 \%$ & $100 \%$ \\
\hline
\end{tabular}

Distribution of Null and Overt subject in the Early Utterances of Tola

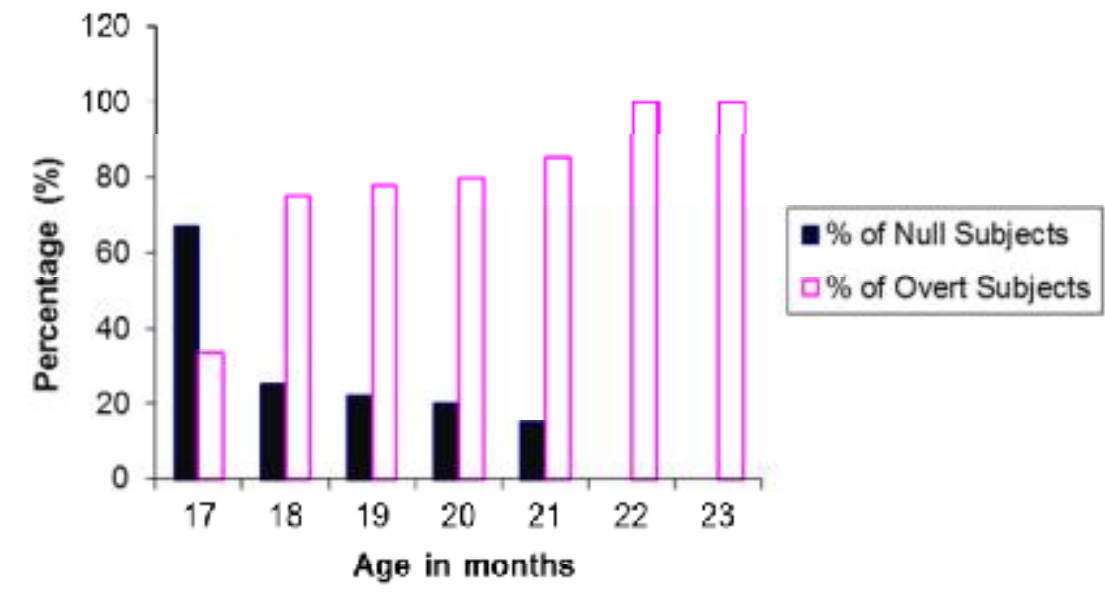

Figure 3. Distribution of Null and Overt Subject in the Early Utterances of Tola

Table 3 and Figure 3 show a gradual decrease in null subjects and a gradual increase in overt subjects. For example, at 17 months, Tola records $66.7 \%$ null subjects and $33.3 \%$ of overt subject while at 21 months, null subjects have dropped to $14.8 \%$ and overt subjects increased to $85.2 \%$ and by 23 months there is no record of null subject as it has dropped to $0 \%$ and overt subjects have taken over with $100 \%$. Looking figure 3 above, we see that Tola's null subjects begin at $66.7 \%$ and gradually move to $0 \%$ while her overt subjects begin at $33.3 \%$ and move to the highest level of $100 \%$. The line shows an increase and a decrease in null and overt 


\section{International Journal of Applied Linguistics \& English Literature}

ISSN 2200-3592 (Print), ISSN 2200-3452 (Online)

Vol. 1 No. 5; September 2012 [Special Issue on General Linguistics]

subjects respectively. From this analysis, it is very clear that as the language of the Yoruba child develops, null subjects give way for overt subjects.

At the initial stage, the one word stage, the child uses only verbal items which are regarded as action words and nominal items. By the time the child moves to the two-word stage, the vocabulary has been expanded widely. At that stage, he begins to combine words. Other lexical items have also entered the lexicon. There is however the preponderance of missing arguments, especially subjects in their speech. This gives credence to the earlier claim made that missing subjects are more readily licensed than missing objects. Examples (5), (6) and (7) illustrate these in the speech of the three longitudinal children at eighteen months.

5. a. jẹ isu

eat yam

'I want to eat yam.' Damilare

b. kpa á

kill it

'I killed it.' Damilare

6. a. fẹ tọ

want urinate

'Want to urinate' Temiloluwa

b. gbe ẹsẹ

carry leg

'carry your leg' Temiloluwa

7. a gbé e

carry it

'I carried it.'

Tola

b. sùn

sleep

'I want to sleep.' Tola

The speech of the children represents a simple case of merging especially for transitive verbs as intransitive verbs would occur without any complement. The diagrams in (8) and (9) below illustrate this.

8.

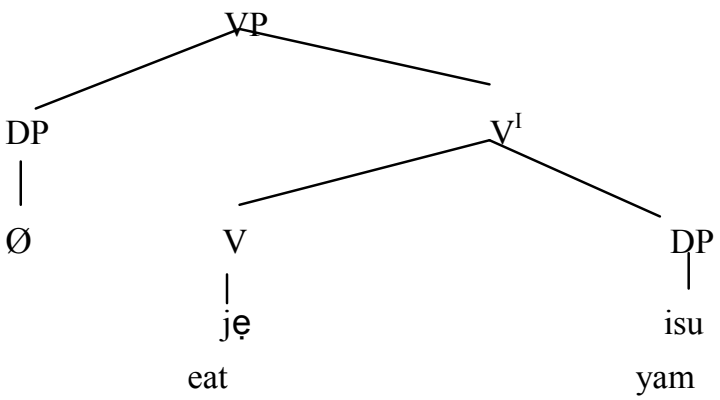

"ate yam"

9.

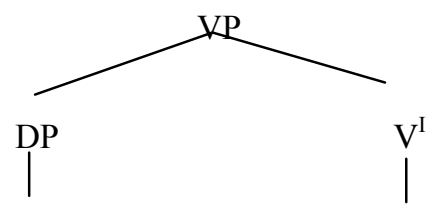

$\varnothing$ 
International Journal of Applied Linguistics \& English Literature

ISSN 2200-3592 (Print), ISSN 2200-3452 (Online)

Vol. 1 No. 5; September 2012 [Special Issue on General Linguistics]

sùn

Sleep

Diagram (8) represents the structure of a transitive verb while (9) represents the structure of an intransitive verb. We could safely say that at this stage, the speech of the child is yet to project to a full clause as all tense and agreement are absent. Deprez and Pierce (1993) claim that the grammar of children differs from that of the adult not because they lack functional categories or movement but because they allow the subject NP to remain in the VP.

Works on missing arguments in the generative framework have characterised argument ellipsis using different parameters. (Hyams 1983, 1986, 1992, 1994) sees missing subjects in terms of the pro-drop parameter. Radford (2000) sees null arguments as null nouns which are given a null spell-out by virtue of representing given information. The Prominence theory also assumes that it is easier for the subject to be missing because it is the external argument which is higher up on the scale and therefore more prominent than other arguments

We assume in this study that null arguments in the early speech of the Yoruba child arise due to different reasons. We are constrained to examine only the generative syntactic reasons. We believe that missing arguments are syntactically active and represented even though they are phonetically null; silent and invisible (cf. Balogh and Grodzinky, 2000). This means that they are implicit arguments; inherent and unspoken. Following Radford (2000), most often, null arguments in the speech of the Yoruba child are given null spell-out because the child feels it is given information. The problem however is that given information needs to be shared by the speaker and the listener, this fact the child does not seem to know at this stage, hence missing arguments.

\section{Argument ellipses are not dependent on finiteness.}

On the relationship between Finiteness and Null Arguments, we predict that there is no direct relationship between the acquisition of finiteness and the end of null arguments. There is ample cross-linguistic evidence to show that early child grammars are devoid of TENSE (Brown 1973, Hyams 1986, Aldridge 1989 and Radford 1991). We discovered from the data of the children that subjects of finite sentences are hardly omitted. This is shown in Table 4.

Table 4. Overt Subjects and Finiteness

\begin{tabular}{|c|c|c|c|}
\hline \multicolumn{2}{|c|}{ Damilare 21- 23 months } & \multirow{2}{*}{$\begin{array}{r}\text { Finite Clauses } \\
59.2 \%\end{array}$} & \multirow[t]{3}{*}{ Non-Finite Clauses } \\
\hline Overt subject & $96.3 \%$ & & \\
\hline Null subject & $3.75 \%$ & $40.8 \%$ & \\
\hline \multicolumn{4}{|c|}{ Temiloluwa 17-21 months } \\
\hline Overt subject & $100 \%$ & $66.7 \%$ & \\
\hline Null subject & $0 \%$ & $33.3 \%$ & \\
\hline \multicolumn{4}{|c|}{ Tola 17-21 months } \\
\hline Overt subject & $100 \%$ & $50 \%$ & \\
\hline Null subject & $0 \%$ & $50 \%$ & \\
\hline
\end{tabular}

From the table above and as stated earlier, we deduce that most utterances with modals which we classify as finite always have overt subjects. This does not necessarily mean that the acquisition of finiteness signifies the end of null arguments as most non-finite clauses in the child's utterances come with null subjects. From the one-word stage to the two-word stage, the children are yet to acquire finiteness.
10. a. gbé e
Damilare 18 months
carry it
'Mummy carry me.'
b. màmá sùn
mummy sleep
'Mummy is sleeping.' 
International Journal of Applied Linguistics \& English Literature

ISSN 2200-3592 (Print), ISSN 2200-3452 (Online)

Vol. 1 No. 5; September 2012 [Special Issue on General Linguistics]
c. mummy nà á
Damilare 18 months
mummy beat it
'Mummy beat me.'
d. fún mi Temiloluwa 18 months
give me
'Give it to me.'
e. je isu Tola 18 months
eat yam
'I want to eat yam.'

Assuming that modals are base-generated in $\mathrm{T}$ in adult Yoruba, we believe that once the children have acquired modals, they have started the process of acquisition of finiteness in the language. By eighteen months, Temiloluwa and Tola have started to acquire finiteness as evidenced with the use of $t i$ ' have', $\dot{n}$ 'PROG' in their speech. Finiteness also began to appear in Damilare's speech at twenty months. We have the following examples from the children:
11. a. Ó ti yà igbẹ
Temiloluwa 18 months
She has poupou
'She has poupoued.'
b. Temi ti n bọ
Temi be PROG come
'Temi is coming.'
Temiloluwa 18 months
c. ẹsẹ̀ ti $\mathrm{n}$ dùn $\mathrm{mi}$ leg be PROG pain me
Tola 18 months
'My leg is beginning to pain me.'
d. Temi ti sùn
Tola 19 months
Temi has sleep
'Temi has slept.'
e. daddy ti lọ Damilare 20 months
daddy has go
'Daddy has gone.'
f. bàbá ti dé Damilare 22 months
daddy has come
'Daddy has come.'

It should be noted that Yoruba does not really mark finiteness overtly. This means that along with this overt marking with aspectuals, other utterances with no overt marking are also finite. The following examples are taken from Temiloluwa at 21 months:

12. a. ó gbà lọ́wọ́ mi she take from hand my

'She took it from me.'
b. ó gbé omi sáré
He carry water run
'He carried the water and ran.'
c. mo fẹ́ lọ sùn
I want go sleep
'I want to go and sleep.'

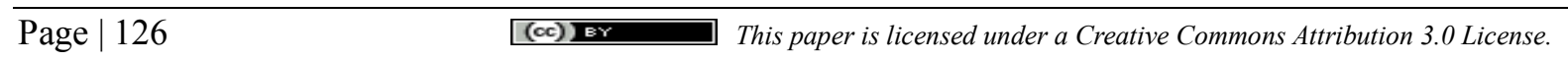


Over time, the usage of finite sentences becomes very frequent. We note that most of the finite utterances of the children have subjects. The finite utterances in Damilare's speech that lacks subjects are used like imperatives. For example:
13. a. ti tán
Damilare 21 months
has finish
'It has finished.'
b. ti tó Damilare 23 months has enough
'It is enough.'

The absence of tense allows null subjects but does not disallow overt subject. This means that the beginning of the acquisition of finiteness does not signify the end of null subjects. The reason for this is that at the same time the children use overt subjects with finite sentences, they also use null subjects with non-tensed sentences. This stage signifies a reduction and eventual take-over of overt subjects from null subjects. At this point, it is clear that the children have acquired finiteness. At this stage in the syntax of the children, the subject that hitherto had remained in spec-VP before the acquisition of finiteness has now moved to spec-TP as illustrated below.

14.

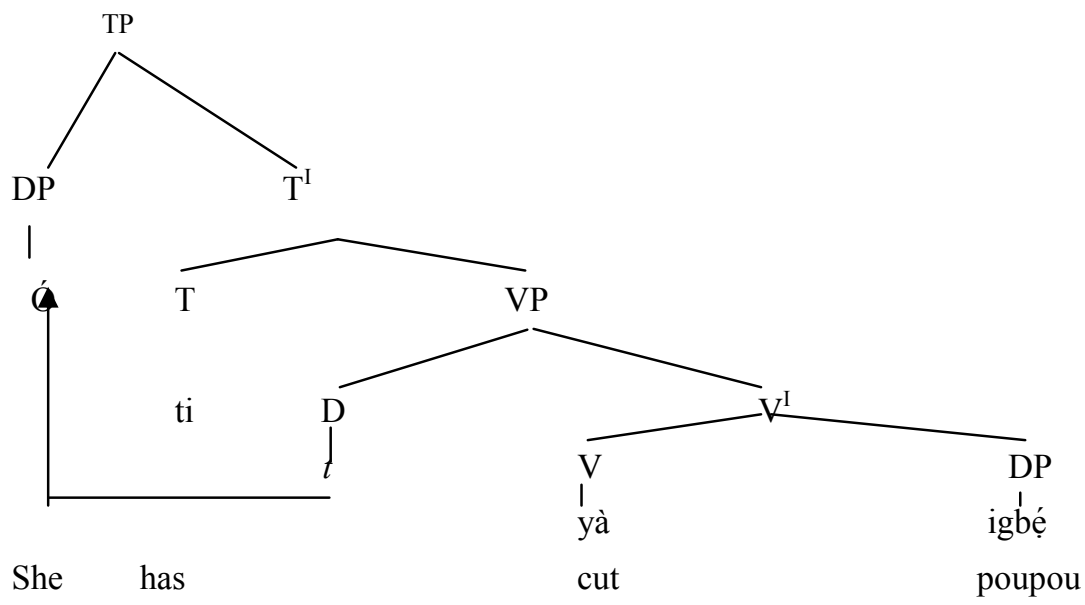

'She has poupoued.'

We can see from the diagram above that the subject $o$ 'she' originated from the spec-VP which is a position of merger and where it is theta-marked and moves to spec-TP where it can have its case checked. It is a case of internal movement, a situation where a constituent moves because it has to move. We also assume that at this stage, the case feature that was uninterpretable has become interpretable to the children.

By the time the Yoruba child is three years old, null arguments have given way to overt arguments in his utterances. The implication of this is that, all the children's sentences are finite. This is in consonance with previous findings that children have acquired finiteness from age two (Aldrige 1989, Radford 1990, 1991). We believe that language acquisition involves incremental feature-building which has a direct relationship with cognitive maturation. By comparing the children at different ages, we can see that as they mature cognitively, they are able to make use of more complex features. This also gives credence to the fact that with age and further cognitive development, null arguments disappear in the utterance of the Yoruba child while overt arguments take over.

\section{Conclusion}

Four research questions were asked under this sub-heading. It is a known fact across languages; children miss out arguments at the initial stage of acquiring their language. We discover a preponderance of null subjects at the early stage of the Yoruba children's acquisition of argument structure. The children's use of null arguments characterizes a case of null PF-spell-out. They take the missing subjects as given information. We also discovered that null subjects are more prominent in the speech of the children than null objects and also that they decrease with age. As the amount of overt subjects increase there is a co relational decrease in null subjects in the utterances of Yoruba children.

We conclude following Radford (2000), that most often, null arguments in the speech of the Yoruba child are 
International Journal of Applied Linguistics \& English Literature

ISSN 2200-3592 (Print), ISSN 2200-3452 (Online)

Vol. 1 No. 5; September 2012 [Special Issue on General Linguistics]

given null spell-out because the child feels it is given information. The problem however is that given information needs to be shared by the speaker and the listener, this fact the child does not seem to know at this stage, hence missing arguments. We assume that by the time the Yoruba child is three years old, null arguments have given way to overt arguments in his utterances. We did not find any direct relationship between null arguments and finiteness, however, we saw that most of their finite sentences have overt subjects and only non-tensed sentences have null subjects.

A major characteristic of this stage we discovered and this also have cross-linguistic back-up is the issue of null arguments. We discovered that the Yoruba child misses the subject but hardly miss out the object. The reason for this is that the language does not license object omission at any level. The subject is also easily omitted for various reasons. One, according to the prominence theory, the subject is the most prominent argument and so can be missed out; the child takes it as given information. The second reason is because, at this stage, the child has not acquired tense and so cannot check the NOMINATIVE case of the subject.

\section{References}

Aldridge, M. (1989). 'The acquisition of INFL'. Indiana University Linguistics Club Publications: Bloomington. Allen, E. M. S. (2000). 'A discourse-pragmatic explanation for argument representation in child Inuktitut.' In Linguistics: an Interdisciplinary Journal of the Language Sciences. http//findarticles.com/p/articles/mi_hb195/is_3_38/ai_n28797777

Aronoff, J. M. (2003) 'Null subjects in child language: evidence for a performance account.' In Garding G. and Tsujimura, (ed.) WCCFL 22 Proceedings, Somerville, MA: Cascadilla Press. 43-55.

Balogh, J. and Y. Grodzinky. (2000). 'Levels of linguistic representation in broca's aphasia: implicitness and referentilaity of arguments'. In Bastiaanse R. and Y. Grodzinsky (eds.). Grammatical Disordersin Aphasia : a Neurolinguistic Perspective. London: Whurr Publishers. http://freud.tau.ac.il/ yosef1/papers/bast.pdf. retrieved on 30th, March, 2010.

Bavin, E. (2000) 'Introduction: a Functional Approach to Ellipsis.' In Linguistics: an Interdisciplinary Journal of the Language Sciences. http//findarticles.com/p/articles/mi_hb195/is_3_38/ai_n28797777

Brown, R. (1973). A first language: the early stages. Cambridge, Mass.: Harvard University Press.

Cabré Sans Y. and Gavarró A. (2006). 'Subject distribution and verb classes in child Catalan'. Cascadilla Proceedings Project.

Carnie, A. (2002). Syntax; a Generative Introduction. Oxford: Blackwell.

Chomsky, N. (1995). The Minimalist Programme. Cambridge, Mass.: The MIT Press.

Chomsky, N. (1999). 'Derivation by Phase'. MIT Occasional Papers in Linguistics 18. Cambridge, Mass: MITWPL.

Chomsky, N. (2004). 'Beyond Explanatory Adequacy. Structures and Beyond.' In Belletti Adriana (ed.). The Cartography of Syntactic Structure. Volume 3. Oxford: OUP. 104-131.

Cook, V. (1996). 'Minimalism, Vocabulary and L2 Learning.' Paper presented at AILA, Jyvaskyla, 1996. www.homepage.ntlworld.com/vivian.c/Writings/Papers/AILA96.htm retieved on 25th January, 2010.

Deprez, V. and A. Pierce (1993) 'Negation and functional projections in early grammar', Linguistic Inquiry 24(1), 25-67.

Grüter, T. (2006). Object clitics and null objects in the acquisition of French. Doctoral Dissertation, McGill University.

Grüter, T. (2007). 'Investigating object drop in child French and English: a truth value judgment task.' In Alyona Belikova, Luisa Meroni, and Mari Umeda (ed.), Proceedings of the 2nd Conference on Generative Approaches to Language Acquisition North America(GALANA), Somerville, MA: Cascadilla Proceedings Project. www.lingref.com, document \#1551. 102-113.

Haegeman, L. (1994) Introduction to government and binding theory. Oxford: Blackwell.

Huang, C.-T J. (1982). Logical relations in Chinese and the theory of grammar. Ph.D dissertation, MIT. Hyams, N. (1983). Acquisition of parameterized grammars. Doctoral dissertation, CUNY, New York. 
International Journal of Applied Linguistics \& English Literature

ISSN 2200-3592 (Print), ISSN 2200-3452 (Online)

Vol. 1 No. 5; September 2012 [Special Issue on General Linguistics]

Hyams, N.. (1986). Language acquisition and the theory of parameters. Dordrecht: Reidel.

Hyams, N. and K. Wexler. (1993). Grammatical basis of null subjects in child language. Linguistic Inquiry 24, $421-459$

Krämer, I. (1993). The licensing of subjects in early child language. In Colin Phillips (ed.), Papers on case \& agreement II, MIT Working Papers in Linguistics 19, 197-212.

Lechner, W. (2006). 'Economy in Minimalist Syntax.'

http:/www2.sfs.nphil.uni-tuebingen.de/nnsle01/1Minimalism.pdf. retrieved on $9^{\text {th }}$ Of March, 2010.

Lee, T. H. (2000). 'Finiteness and null arguments in child Cantonese.' In The Tsinghua Journal of Chinese Studies, New Series, Vol. 30, No. 1, 101-128.

Longa, V. M. G. Lorenzo (2008). 'What about a 'really' Minimalist Theory of Language Acquisition?' in Linguistics. Walter de Gruyter GmbH \& Co. KG. 46-3, 541-570.

Lorusso, P., C. Caprin and M. T. Guasti. (2004). 'Overt subjects distribution in early Italian children.' Boston University Conference on Language Development, Boston.

Poeppel, D. and K. Wexler (1993). 'The full competence hypothesis of clause structure in early German. Language, Volume 69, No 1, 1-33.

Radford, A. (1990). Syntactic theory and the acquisition of English syntax: the nature of early child grammars of English. Basil Blackwell: Oxford.

Radford, A. (1991). 'Small children's small minds'. Essex Occasional Papers in Linguistic. Volume 32, 83-109.

Radford, A. (1997) Syntax: A Minimalist Introduction Cambridge: Cambridge University Press.

Radford, A. (2000). 'Children in search of perfection: towards a minimalist model of acquisition'. In Essex Research in Linguistics, Vol. 34, 57-74.

Radford, A. (2004) Minimalist Syntax: Exploring the Structure of English. Cambridge: Cambridge University Press.

Rohrbacher, B. and A. Vainikka (1994). 'On German verb syntax under age two.' In Institute for Research in Cognitive Science. http://repository.upenn.edu/ircs_reports/170.

Rowland, E. C. (1969) Teach yourself Yoruba. London: The English University Press.

Sano, T. and N. Hyams. (1994). 'Agreement, finiteness, and the development of null arguments'. Proceedings of NELS 24:543-558.

Uziel-Karl, S. (2001). 'Where's Ellipsis? Whether and why there are missing arguments in Hebrew child language'. In Linguistics: an Interdisciplinary Journal of the Language Sciences.

http//findarticles.com/p/articles/mi_hb195/is_3_38/ai_n28797777

Uziel-Karl, S. and R. A. Berman. (2000). "Where's ellipsis? whether and why there are missing arguments in Hebrew child language". Linguistics 38, 457-482.

Wang, Q., D. Lillo-Martin, C. Best and A. Levitt. (1992). Null subjects and objects acquisition of Chinese. Language Acquisition 2, 221-254. 